\title{
Chlorpyrifos and persistent organic pollutants in feathers of the near threatened Olrog's Gull in southeastern Buenos Aires Province, Argentina ${ }^{\text {is }}$
}

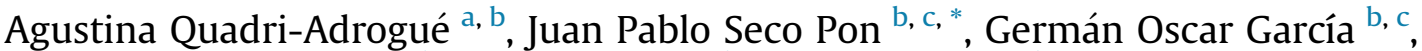 \\ Melina Vanesa Castano ${ }^{\text {b, c }}$, Sofia Copello ${ }^{\text {b, c }}$, Marco Favero ${ }^{\text {b, c }}$, \\ Karina Silvia Beatriz Miglioranza ${ }^{\text {a, }}$ c \\ a Laboratorio de Ecotoxicología y Contaminación Ambiental, Universidad Nacional de Mar del Plata, Funes, 3350, Mar del Plata (7600), Argentina \\ ${ }^{\mathrm{b}}$ Laboratorio de Vertebrados, Universidad Nacional de Mar del Plata, Funes, 3350, Mar del Plata (7600), Argentina \\ ${ }^{\mathrm{c}}$ Instituto de Investigaciones Marinas y Costeras (IIMyC) (UNMDP-CONICET), Argentina
}

\section{A R T I C L E I N F O}

\section{Article history:}

Received 24 June 2020

Received in revised form 19 October 2020

Accepted 22 October 2020

Available online $\mathrm{xxx}$

\section{Keywords:}

Chlorpyrifos

Persistent organic pollutants

Olrog's Gull

Body feathers

South America

\begin{abstract}
A B S T R A C T
The use of bird feathers to assess environmental contamination has steadily increased in ecotoxicological monitoring programs over the past decade. The Olrog's Gull (Larus atlanticus) is a species endemic to the Atlantic coast of southern South America, constituting one of the three threatened gull species listed in the entire American continent. The aim of this study was to assess the exposure to Persistent Organic Pollutants (POPs) and chlorpyrifos in the Near Threatened Olrog's Gull through the analysis of body feathers sampled at the Mar Chiquita coastal lagoon, the main wintering area of the species in Argentina, controlling for sex and age class. Chlorpyrifos showed the highest concentrations among all contaminants and groups of individuals $\left(\overline{\mathrm{X}}=263 \mathrm{ng} \mathrm{g}^{-1}\right)$, while among POPs the concentration of organochlorine pesticides was higher than polychlorinated biphenyls and polybrominated diphenyl ethers, likely indicating the current use of these agricultural contaminant in the region. The highest values of total POP concentrations (males $\bar{X}=280 \mathrm{ng} \mathrm{g}^{-1}$, females $\bar{X}=301 \mathrm{ng} \mathrm{g}^{-1}$ ) were found in juvenile gulls, likely as a consequence of the incorporation of pollutants during the breeding season. Subadult and adult birds showed difference between sexes in the concentration of contaminants, with higher levels in males than females. The results highlight the need to include birds of different sex and age classes in order to better understand the variation in pollutants loads. The present study provides relevant information to improve the conservation status of the Olrog's Gull and new insights about the environmental health of the Mar Chiquita coastal lagoon, Argentina, a MAB-UNESCO World Biosphere Reserve. However, there is a continued need for long-term monitoring programs focusing on this threatened species to understand the effects of pollutants on its population.
\end{abstract}

(C) 2020 Elsevier Ltd. All rights reserved.

\section{Author contribution}

Agustina Quadri Adrogué, Data curation, Formal analysis, Investigation, Methodology, Software, Visualization, Writing original draft, reviewing and editing. Juan Pablo Seco Pon: Conceptualization, Formal analysis, Investigation, Methodology,

\footnotetext{
This paper has been recommended for acceptance by Da Chen.

* Corresponding author. Laboratorio de Vertebrados, Universidad Nacional de Mar del Plata, Funes 3350, Mar del Plata (7600), Argentina.

E-mail address: secopon@mdp.edu.ar (J.P. Seco Pon).
}

Resources, Software, Supervision, Writing-reviewing and editing. Germán García: Data curation, Investigation, Writing-reviewing and editing. Melisa Castano: Data curation, Investigation. Sofía Copello: Data curation, Investigation. Writing-reviewing and editing. Marco Favero: Funding acquisition, Investigation, Methodology, Writing-reviewing and editing. Karina S.B. Miglioranza: Conceptualization, Data curation, Formal analysis, Funding acquisition, Investigation, Methodology, Project administration, Resources, Supervision, Writing-reviewing and editing. 


\section{Introduction}

The use of bird feathers to assess environmental contamination has steadily increased in ecotoxicological monitoring programs over the past decade (Abbasi et al., 2017, Behrooz et al., 2009, García-Fernández et al., 2013, Jaspers et al., 2011 and 2019, Monclús et al., 2018, Quadri Adrogué et al., 2019, among others). This is linked to the fact that feathers provide a non-destructive matrix when compared to internal body organs, and pollutants loads in feathers are strongly correlated with internal body burdens (Eulaers et al., 2011; García-Fernández et al., 2013; Jaspers et al., 2006). On the other hand, birds are well-studied organisms in terms of their biology and ecology, thus enhancing their usefulness as biomonitors (Furness et al., 1993; Burger and Gochfeld 2004). Besides, they tend to be at relatively high levels in the food chain, being suitable to accumulate contaminants through their (long) life providing retrospective assessment of long-term contamination exposure (Furness et al., 1993; Sun et al., 2020). Persistent Organic Pollutants (POPs) spanning from organochlorine pesticides (OCPs), polychlorinated biphenyls (PCBs) to polybrominated diphenyl ethers (PBDEs), have been frequently measured in birds' feathers (Acampora et al., 2017; Behrooz et al., 2009; García-Fernández et al., 2013; Quadri Adrogue et al., 2019). POPs were globally used for industrial and agricultural purposes, though they are currently forbidden at worldwide level, and regulated by the Stockholm Convention (UNEP 2011). However, their long environment persistence and the long-range transport, in addition to some illegal uses, lead POPs to be found in different environmental matrices (Durante et al., 2016, Gómez-Ramírez et al., 2012; Miglioranza et al., 1999, 2013a, 2013b, Monclús et al., 2018, Qiu et al., 2019).

One important concern about POPs is related to the adverse effects on biota due to their physical-chemical properties, leading moreover to bioaccumulation and biomagnification through the food chain (Alharbi et al., 2018; Jaspers et al., 2006; Lohmann et al., 2007; Ondarza et al., 2014). Endosulfan was the last OCPs to be included in the Stockolm Convention list (UNEP 2011). After that, the organophosphorus pesticide chlorpyrifos has intensively entered into the agricultural market, thus turning into one of the main insecticide used at worldwide level (Mackay et al., 2014; Miglioranza et al., 2013b). Previous studies have showed that chlorpyrifos have potentially toxic properties affecting several groups of vertebrates, including birds (Eng et al., 2017; Fry 1995; Mitra et al., 2011). Moreover, very few studies have determined the presence of chlorpyrifos in the environment using birds' feathers as bioindicators (see Gervais et al., 2000; Quadri Adrogué et al., 2019).

Feathers have become a preferred method when research involves working with living birds and a non-destructive sampling is required (García-Fernández et al., 2013). This is particularly relevant when considering the conservation status of the studied organism/s, and/or due to local legislation. Pollutants can be transported to feathers by atmospheric deposition, via the connection to the bloodstream during feather growth, or via the preen oil during preening (Wania and Mackay, 1996; GarcíaFernández et al., 2013). Feathers grow during a limited period of time while they are still connected to the blood circulation (Burger 1993). Organic pollutants are soluble in lipids and stored in body fat, during the molt period they may be transferred to feathers via bloodstream (García-Fernández et al., 2013). Therefore, grown feathers allow retrospective assessment of pollutants exposure during their growth. Particularly, body feathers are well known for being strongly correlated with POP's internal body burdens and sampling them seems to be useful when compared to primary feathers (Eulaers et al., 2011; Jaspers et al., 2011). Body feathers are known to be most representative of concentrations of contaminants in plumage as whole in comparison with primary feathers; besides, they can offer a controlled temporal exposure if molting pattern is understood (Gill 2007; Hardy et al., 2006; Jaspers et al., 2011). It has to be stressed that variation in feathers pollutants levels may arise from diet, habitat and/or migratory strategies (Anderson et al., 2010; García-Fernández et al., 2013; Fromant et al., 2016, among others). Moreover, there may be differences due to intrinsic factors such as gender -where females' pollutants loads may be influenced for example by off-loading contaminants during egg formation (Burger and Gochfeld 2002), and age classes -where younger birds are supposed to contain higher body burdens than adults due to the maternal transfer from the egg (Burger et al., 1994; Burger and Gochfeld 2002).

The Olrog's Gull (Larus atlanticus) is a species endemic to the Atlantic coast of southern South America (BirdLife International 2018; Harrison 1984; Olrog 1967; Yorio et al., 1998), and along with L. fuliginosus and L. heermani constitutes the three threatened gull species listed in the entire American continent (BirdLife International 2018). The breeding range of $L$. atlanticus is restricted to only two nesting areas and 18 breeding colonies along $2500 \mathrm{~km}$ of the central Argentinean coast between $39^{\circ} 12^{\prime}-45^{\circ} 11^{\prime} \mathrm{S}$ (Yorio et al., 2013). The main breeding area of the species is located in the Bahía Blanca estuary (García Borboroglu and Yorio 2007; Yorio et al., 1998), which is subject to intense human pressures ranging from urban development, industry, agriculture, recreation, fishing, pollution and even egging (Yorio et al., 2005, 2013). The entire breeding population has been estimated at approximately 5000-8000 pairs (Yorio et al., 2013). The species is listed as Near Threatened by the International Union for the Conservation of Nature (IUCN) (BirdLife International 2018) and is included in Appendix I of the Convention on Migratory Species chiefly due to its restricted breeding range and conservation threats allied to breeding sites (CMS 2018). At a national scale, the species is listed as Vulnerable both in Argentina and Uruguay (MAyDS and AA 2017). The Olrog's Gull seems to be one of few gulls with rather specialized feeding habits preying primarily on grapsid crabs at its breeding grounds (Devillers 1977; Herrera et al., 2005; Olrog 1967) and also in its wintering areas in northern Patagonia (Berón 2003; Berón and Favero 2010; Copello and Favero 2001; Spivak and Sánchez 1992). Outside the breeding season, the species is not restricted to estuaries, and it appears to be a more generalist forager, at least in Buenos Aires Province (Berón et al., 2007; Martínez et al., 2000; Olrog 1967).

The main objectives of the present study were to i) to assess the concentrations of chlorpyrifos, OCPs, PCBs and PBDEs in feathers of the Olrog's Gull during the non-breeding season; and ii) to analyze the relationship of feathers' pollutant levels with intrinsic biological factors such as sex and age class.

\section{Materials and methods}

\subsection{Sampling area and collation of samples}

Sampling was conducted in the Mar Chiquita coastal lagoon, the most important wintering ground of the Olrog's Gull in Argentina (Fig. 1). This area is also one of the main sites of Buenos Aires Province in regards to biodiversity (Iribarne 2001; Isacch et al., 2016). Due to its unique environmental features it was declared a World Biosphere Reserve by MAB-UNESCO in 1996 and a Provincial Reserve in 1999 (Isacch 2008). Interestingly, this area is located in the core of the large part of the human population and the agricultural and livestock production of the region (Laterra et al., 2019; Soriano et al., 1991), and consequently it is one of the most 


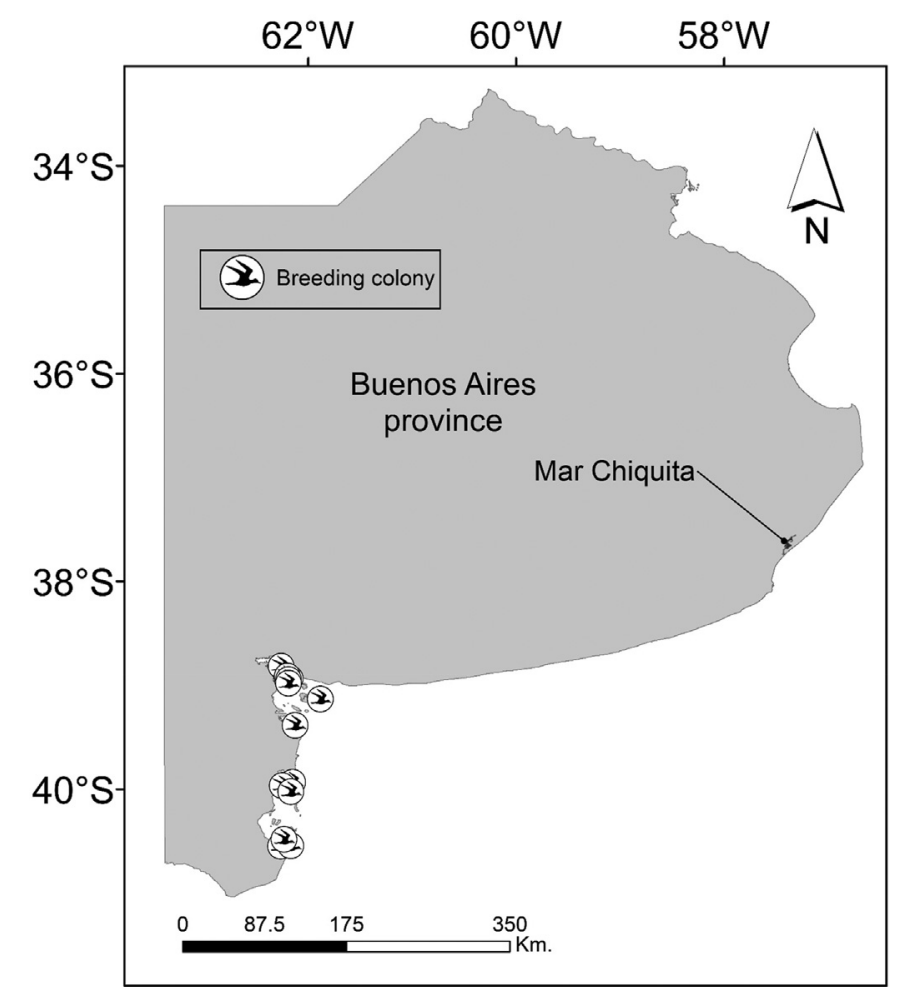

Fig. 1. Geographical localization of Mar Chiquita coastal lagoon in the south-western Atlantic of Argentina. Depicted are known breeding colonies of the Olrog's Gull (Larus atlanticus) within the Buenos Aires Province.

threatened biomes of South America (Isla and Lasta 2006, 2010). Furthermore, the lagoon and adjacent coastal waters are exploited by a number of different sport (Lucifora 2001) and small-scale coastal fisheries (Seco Pon et al., 2012). This environment is regularly used by Olrog's Gull of different age classes with varying abundances throughout the year (Berón et al., 2012).

A total of 41 birds (24 juveniles, 10 subadults and 7 adults) were captured with a noose carpet (Bloom 1987) in Mar Chiquita coastal lagoon during the non-breeding seasons of 2013, 2014 and 2016. Samples from all individuals included $3-5$ body feathers (a random pinch of body feathers were plucked from the right side of the bird breast) collected immediately after the capture, and stored individually in paper envelopes until analysis. The age classes (juvenile, subadult and adult) were determined by plumage, beak and leg coloration (Harrison 1984). Approximately $0.1 \mathrm{~mL}$ of blood was obtained from the braquial vein using 3 cc syringes and $25 \mathrm{G} \mathrm{x} 1^{\prime \prime}$ needles. A few drops of blood were placed on a small piece of commercial filter paper, air-dried and stored separately for molecular sex determination (Quintana et al., 2008).

\subsection{Sample preparation and extraction of pollutants}

Analytical procedure was carried out according to the method described by Dauwe et al. (2005). In order to remove dust external particles, approximately $15 \mathrm{mg}$ of body feathers were thoroughly submerged in deionized water, while barbs were separated using tweezers. In order avoid external contamination from the lab, feathers were let to dry overnight at ambient temperature in a lab hood. Dried feathers were then cut (roughly $1 \mathrm{~mm}$ ) and relocated in analytical recipients with $5 \mathrm{ml}$ of $\mathrm{HCl}(4 \mathrm{M})$ and $3 \mathrm{ml}$ of hexane:dichloromethane $(4: 1, \mathrm{v} / \mathrm{v})$; PCB 103 was used as internal standard. Samples were incubated at $40{ }^{\circ} \mathrm{C}$ for about $12 \mathrm{~h}$. Before both liquid-liquid extractions, $4 \mathrm{ml}$ of hexane:dichloromethane $(4: 1, \mathrm{v} / \mathrm{v})$ was affixed to all samples. Afterwards, supernatants (organic fractions) were transferred into a new glass recipient and evaporated with $\mathrm{N}_{2}$ and cleaned up with silica gel chromatography. Finally, the extracts were placed in a chromatographic vial and stored at $-20^{\circ} \mathrm{C}$ until gas chromatographic analysis.

\subsection{Gas chromatographic analysis}

Compounds were identified and quantified according to Miglioranza et al. (2003). Chlorpyrifos, OCPs ( $\alpha$ - and $\beta$-endosulfan, endosulfan sulfate, $\alpha$ - and $\gamma$-chlordane, $p, p^{\prime}$-DDT, $p, p^{\prime}$-DDE, $p, p^{\prime}-$ DDD, aldrin, endrin, dieldrin, endrin ketona, $\alpha-, \beta-, \gamma-$ and $\delta-\mathrm{HCH}$, metoxichlor, heptachlor, heptachlor epoxide), PCBs congeners (PCB $-8,-18,-31+28,-33,-52,-49,-44,-70+95,-66,-56+60$, $-101,-99,-97,-87,-110,-118,-105,-151,-123+149,-153$ $+132,-141,-138,-158,-128,-156,-187,-183,-174,-177$ and -180 ), and PBDEs (\#28, 47, 99, 100, 153, 154, and 138) were examined by gas chromatography equipped with electron-capture detector (GC-ECD) using a Shimadzu 17A chromatograph. A fusedsilica SPB-5 capillary column (30 m, $0.25 \mathrm{~mm}$ i. d., $0.25 \mu \mathrm{m}$ film thickness, Supelco, Bellefonte, PA, USA) was used. For details on temperature conditions see Miglioranza et al. (2003).

\subsection{Quality assurance/quality control (QA/QC)}

Procedural and instrumental blanks were analyzed and compounds levels were below the detection limits. Recoveries of the internal standard (PCB \#103) and pesticides were estimated by spiking feathers, resulting in values greater than 90\% for PCB \#103 and mean values of 87.41 (endosulfans), 104.63 (HCHs), 89.21 (DDTs), 85.21 (chlordanes), and 109.29 (heptachlors). Instrumental detection limits, calculated according to methods described by Keith et al. (1983), ranged between 0.15 and $1 \mathrm{ng} \mathrm{g}^{-1}$ for HCHs and between 0.4 and $1.65 \mathrm{ng} \mathrm{g}^{-1}$ for the remaining compounds (Table SM.1).

\subsection{Statistical analysis}

Samples were pooled (as per gender and age-class) and all seasons combined. In the case of samples that showed pollutant concentrations lower than the Limit of Quantification (LOQ), a value resulting from DF $x$ LOQ being DF the detection frequency, was consigned. For statistical analyses, we only included compounds detected in more than $50 \%$ of the measurements above LOQ (e.g. chlorpyrifos, $\alpha$-endosulfan and PCB \#33). The effect of gender and age class (predictor variables) on the concentrations of chloryrifos and POPs was tested with Generalized Linear Models (GLM) with Gamma error distribution and log link function (Crawley 2007). Gender (male and female) and age-class (juvenile, subadult and adult) were included as categorical variables. All analyses were executed using R version 3.6.1. (R Development Core Team 2012). The level of significance in all tests was set to $p<0.05$. All feathers contaminant values are stated as $n g \mathrm{~g}^{-1}$, feather (on a dry weight basis) and as average \pm SD.

\section{Results and discussion}

In total, chlorpyrifos, 17 OCPs, 30 PCBs and 5 PBDEs were detected. Concentrations of such contaminants (mean \pm SD) by sex and age class of the Olrog's Gull are shown in Table 1. 
Table 1

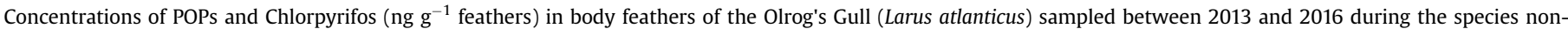

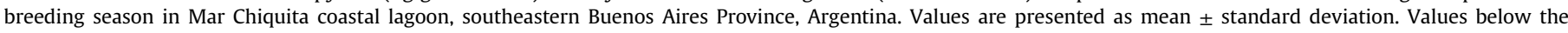
detection limit are depicted as $<\mathrm{dl}$.

\begin{tabular}{|c|c|c|c|c|c|c|c|}
\hline & & \multicolumn{2}{|l|}{ Juveniles } & \multicolumn{2}{|l|}{ Subadults } & \multicolumn{2}{|l|}{ Adults } \\
\hline & \multirow[b]{2}{*}{ chlorpyrifos } & Males $\mathrm{n}=14$ & Females $\mathrm{n}=10$ & Males $\mathrm{n}=6$ & Females $\mathrm{n}=4$ & Males $\mathrm{n}=3$ & Females $\mathrm{n}=4$ \\
\hline & & $154.52 \pm 210.45$ & $74.47 \pm 129.08$ & $1105.21 \pm 1793.63$ & $178.35 \pm 80.38$ & $112.96 \pm 86.60$ & $47.15 \pm 58.81$ \\
\hline \multirow[t]{17}{*}{ OCPs } & $\alpha-\mathrm{HCH}$ & $6.48 \pm 13.96$ & $1.78 \pm 4.16$ & $2.55 \pm 2.95$ & $<\mathrm{dl}$ & $<\mathrm{dl}$ & $<\mathrm{dl}$ \\
\hline & $\beta-\mathrm{HCH}$ & $29.62 \pm 28.26$ & $28.10 \pm 39.92$ & $44.06 \pm 42.25$ & $11.88 \pm 15.95$ & $49.83 \pm 35.36$ & $5.07 \pm 10.14$ \\
\hline & $\gamma-\mathrm{HCH}$ & $4.11 \pm 9.27$ & $7.01 \pm 6.97$ & $11.89 \pm 18.64$ & $1.00 \pm 2.00$ & $<\mathrm{dl}$ & $0.73 \pm 0.88$ \\
\hline & $\alpha$-chlordane & $3.67 \pm 8.11$ & $1.11 \pm 2.06$ & $2.33 \pm 2.66$ & $<\mathrm{dl}$ & $<\mathrm{dl}$ & $0.74 \pm 0.6$ \\
\hline & $\gamma$-chlordane & $3.79 \pm 8.67$ & $2.35 \pm 2.77$ & $3.39 \pm 4.07$ & $<\mathrm{dl}$ & $<\mathrm{dl}$ & $0.21 \pm 0.42$ \\
\hline & $\alpha$-endosulfan & $51.54 \pm 70.07$ & $51.72 \pm 56.77$ & $31.92 \pm 50.38$ & $3.76 \pm 2.52$ & $6.63 \pm 6.64$ & $7.06 \pm 10.99$ \\
\hline & $\beta-$ endosulfan & $2.55 \pm 5.58$ & $2.43 \pm 5.79$ & $2.12 \pm 3.79$ & $<\mathrm{dl}$ & $<\mathrm{dl}$ & $<\mathrm{dl}$ \\
\hline & endosulfan sulfate & $7.12 \pm 9.70$ & $<\mathrm{dl}$ & $9.9 \pm 21.88$ & $8.12 \pm 17.63$ & $4.02 \pm 6.96$ & $0.50 \pm 1.01$ \\
\hline & heptachlor & $8.9 \pm 20.26$ & $3.95 \pm 8.89$ & $7.37 \pm 15.87$ & $1.14 \pm 2.27$ & $<\mathrm{dl}$ & $0.98 \pm 1.97$ \\
\hline & heptachlor epoxide & $7.80 \pm 22.04$ & $0.43 \pm 8.89$ & $6.76 \pm 9.30$ & $5.86 \pm 7.62$ & $<\mathrm{dl}$ & $<\mathrm{dl}$ \\
\hline & dieldrin & $7.91 \pm 16.93$ & $10.59 \pm 14.31$ & $3.8 \pm 8.28$ & $<\mathrm{dl}$ & $<\mathrm{dl}$ & $0.66 \pm 1.33$ \\
\hline & endrin & $7.69 \pm 21.21$ & $<\mathrm{dl}$ & $16.51 \pm 40.44$ & $<\mathrm{dl}$ & $5.40 \pm 9.36$ & $<\mathrm{dl}$ \\
\hline & endrin ketone & $14.53 \pm 54.36$ & $10.01 \pm 31.66$ & $<\mathrm{dl}$ & $<\mathrm{dl}$ & $<\mathrm{dl}$ & $<\mathrm{dl}$ \\
\hline & $p^{\prime} p$-DDD & $3.13 \pm 7.35$ & $22.87 \pm 43.92$ & $1.70 \pm 4.17$ & $12.52 \pm 25.03$ & $<\mathrm{dl}$ & $<\mathrm{dl}$ \\
\hline & p'p-DDE & $19.32 \pm 37.54$ & $6.65 \pm 18.53$ & $3.65 \pm 4.35$ & $<\mathrm{dl}$ & $<\mathrm{dl}$ & $3.29 \pm 3.80$ \\
\hline & p'p-DDT & $<\mathrm{dl}$ & $<\mathrm{dl}$ & $4.34 \pm 9.55$ & $<\mathrm{dl}$ & $10.69 \pm 18.53$ & $<\mathrm{dl}$ \\
\hline & Metoxichlor & $0.42 \pm 1.58$ & $1.52 \pm 4.8$ & $0.47 \pm 1.15$ & $1.68 \pm 3.37$ & $<\mathrm{dl}$ & $<\mathrm{dl}$ \\
\hline \multirow[t]{36}{*}{ PCBs } & 8 & $<\mathrm{dl}$ & $4.86 \pm 15.37$ & $13.58 \pm 24.66$ & $<\mathrm{dl}$ & $<\mathrm{dl}$ & $9.05 \pm 18.11$ \\
\hline & $\Sigma$ dichlor & $<\mathrm{dl}$ & $4.86 \pm 15.37$ & $13.58 \pm 24.66$ & $<\mathrm{dl}$ & $<\mathrm{dl}$ & $9.05 \pm 18.11$ \\
\hline & 18 & $1.04 \pm 2.93$ & $7.49 \pm 23.70$ & $<\mathrm{dl}$ & $<\mathrm{dl}$ & $25.32 \pm 43.86$ & $<\mathrm{dl}$ \\
\hline & $31+28$ & $<\mathrm{dl}$ & $2.03 \pm 4.00$ & $16.69 \pm 26.33$ & $0.92 \pm 1.84$ & $38.41 \pm 66.53$ & $<\mathrm{dl}$ \\
\hline & 33 & $32.26 \pm 61.31$ & $27.93 \pm 22.9$ & $28.94 \pm 33.17$ & $<\mathrm{dl}$ & $5.63 \pm 9.75$ & $7.87 \pm 10.42$ \\
\hline & ¿trichlor & $33.30 \pm 61.08$ & $37.46 \pm 36.22$ & $47.21 \pm 34.57$ & $0.73 \pm 1.64$ & $69.36 \pm 105.86$ & $5.5 \pm 10.99$ \\
\hline & 52 & $0.77 \pm 2.0$ & $12.31 \pm 23.52$ & $10.97 \pm 25.12$ & $<\mathrm{dl}$ & $8.16 \pm 14.14$ & $<\mathrm{dl}$ \\
\hline & 49 & $1.18 \pm 4.42$ & $<\mathrm{dl}$ & $0.25 \pm 0.61$ & $<\mathrm{dl}$ & $<\mathrm{dl}$ & $<\mathrm{dl}$ \\
\hline & 44 & $21.65 \pm 26.72$ & $29.06 \pm 36.08$ & $22.76 \pm 30.64$ & $1.05 \pm 2.10$ & $6.78 \pm 11.74$ & $6.63 \pm 8.47$ \\
\hline & $70+95$ & $<\mathrm{dl}$ & $1.99 \pm 4.62$ & $13.85 \pm 26.97$ & $<\mathrm{dl}$ & $2.41 \pm 4.17$ & $<\mathrm{dl}$ \\
\hline & 66 & $<\mathrm{dl}$ & $0.24 \pm 0.77$ & $<\mathrm{dl}$ & $1.80 \pm 3.6$ & $<\mathrm{dl}$ & $<\mathrm{dl}$ \\
\hline & $56+60$ & $2.75 \pm 6.82$ & $1.58 \pm 4.03$ & $<\mathrm{dl}$ & $<\mathrm{dl}$ & $<\mathrm{dl}$ & $<\mathrm{dl}$ \\
\hline & stetrachlor & $26.34 \pm 26.48$ & $45.19 \pm 46.23$ & $47.83 \pm 63.85$ & $2.28 \pm 3.3$ & $17.35 \pm 24.07$ & $6.63 \pm 8.47$ \\
\hline & 101 & $0.27 \pm 1.02$ & $1.37 \pm 4.33$ & $26.23 \pm 60.22$ & $<\mathrm{dl}$ & $<\mathrm{dl}$ & $0.57 \pm 1.15$ \\
\hline & 99 & $0.49 \pm 1.25$ & $3.32 \pm 7.06$ & $8.79 \pm 21.54$ & $<\mathrm{dl}$ & $<\mathrm{dl}$ & $<\mathrm{dl}$ \\
\hline & 97 & $2.21 \pm 4.61$ & $0.34 \pm 1.09$ & $0.31 \pm 0.75$ & $<\mathrm{dl}$ & $<\mathrm{dl}$ & $<\mathrm{dl}$ \\
\hline & 87 & $1.11 \pm 3.16$ & $4.10 \pm 12.96$ & $1.17 \pm 2.37$ & $<\mathrm{dl}$ & $<\mathrm{dl}$ & $<\mathrm{dl}$ \\
\hline & 110 & $3.39 \pm 8.27$ & $4.97 \pm 9.16$ & $2.95 \pm 3.42$ & $<\mathrm{dl}$ & $<\mathrm{dl}$ & $0.34 \pm 0.69$ \\
\hline & 118 & $4.47 \pm 10.03$ & $2.65 \pm 5.72$ & $<\mathrm{dl}$ & $4.48 \pm 8.96$ & $5.45 \pm 9.44$ & $<\mathrm{dl}$ \\
\hline & 105 & $4.20 \pm 7.00$ & $0.99 \pm 2.49$ & $<\mathrm{dl}$ & $<\mathrm{dl}$ & $<\mathrm{dl}$ & $<\mathrm{dl}$ \\
\hline & spentachlor & $16.16 \pm 18.02$ & $17.75 \pm 18.11$ & $38.45 \pm 84.02$ & $4.77 \pm 7.79$ & $5.45 \pm 9.44$ & $1.26 \pm 0.95$ \\
\hline & 151 & $<\mathrm{dl}$ & $0.37 \pm 0.87$ & $0.58 \pm 1.42$ & $<\mathrm{dl}$ & $<\mathrm{dl}$ & $<\mathrm{dl}$ \\
\hline & $149 / 123$ & $0.67 \pm 2.53$ & $6.10 \pm 18.16$ & $2.78 \pm 6.8$ & $<\mathrm{dl}$ & $<\mathrm{dl}$ & $<\mathrm{dl}$ \\
\hline & $153+132$ & $4.54 \pm 9.80$ & $16.37 \pm 28.97$ & $17.58 \pm 30.24$ & $1.10 \pm 2.2$ & $2.18 \pm 3.79$ & $2.38 \pm 4.76$ \\
\hline & 141 & $2.07 \pm 4.42$ & $<\mathrm{dl}$ & $<\mathrm{dl}$ & $<\mathrm{dl}$ & $<\mathrm{dl}$ & $1.42 \pm 2.49$ \\
\hline & 138 & $1.65 \pm 3.62$ & $15.10 \pm 40.89$ & $6.51 \pm 10.65$ & $<\mathrm{dl}$ & $<\mathrm{dl}$ & $<\mathrm{dl}$ \\
\hline & 158 & $<\mathrm{dl}$ & $0.38 \pm 1.20$ & $<\mathrm{dl}$ & $0.83 \pm 1.66$ & $<\mathrm{dl}$ & $0.43 \pm 0.86$ \\
\hline & 128 & $<\mathrm{dl}$ & $0.55 \pm 1.18$ & $0.57 \pm 0.91$ & $0.62 \pm 1.24$ & $<\mathrm{dl}$ & $<\mathrm{dl}$ \\
\hline & 156 & $<\mathrm{dl}$ & $1.78 \pm 4.03$ & $2.41 \pm 3.81$ & $<\mathrm{dl}$ & $<\mathrm{dl}$ & $<\mathrm{dl}$ \\
\hline & ¿hexachlor & $8.95 \pm 9.56$ & $40.66 \pm 86.54$ & $29.20 \pm 41.71$ & $3.81 \pm 4.01$ & $2.19 \pm 3.79$ & $4.66 \pm 3.96$ \\
\hline & 187 & $2.29 \pm 4.86$ & $2.12 \pm 6.69$ & $0.69 \pm 1.69$ & $<\mathrm{dl}$ & $<\mathrm{dl}$ & $<\mathrm{dl}$ \\
\hline & 183 & $2.16 \pm 3.85$ & $0.82 \pm 1.77$ & $3.08 \pm 6.79$ & $4.89 \pm 5.93$ & $4.65 \pm 8.06$ & $3.45 \pm 3.47$ \\
\hline & 174 & $1.10 \pm 4.13$ & $<\mathrm{dl}$ & $0.47 \pm 0.97$ & $<\mathrm{dl}$ & $<\mathrm{dl}$ & $0.56 \pm 1.12$ \\
\hline & 177 & $1.49 \pm 3.83$ & $3.05 \pm 9.66$ & $0.43 \pm 1.04$ & $3.55 \pm 7.11$ & $<\mathrm{dl}$ & $<\mathrm{dl}$ \\
\hline & 180 & $0.54 \pm 1.5$ & $<\mathrm{dl}$ & $0.52 \pm 0.95$ & $<\mathrm{dl}$ & $<\mathrm{dl}$ & $<\mathrm{dl}$ \\
\hline & sheptachlor & $7.58 \pm 8.27$ & $6.00 \pm 11.84$ & $4.40 \pm 7.20$ & $7.71 \pm 5.68$ & $4.65 \pm 8.06$ & $6.57 \pm 4.33$ \\
\hline \multirow[t]{6}{*}{ PBDEs } & BDE 28 & $4.40 \pm 16.47$ & $10.39 \pm 32.84$ & $<\mathrm{dl}$ & $<\mathrm{dl}$ & $<\mathrm{dl}$ & $<\mathrm{dl}$ \\
\hline & BDE 47 & $3.06 \pm 11.44$ & $13.42 \pm 36.83$ & $<\mathrm{dl}$ & $<\mathrm{dl}$ & $<\mathrm{dl}$ & $<\mathrm{dl}$ \\
\hline & BDE 66 & $<\mathrm{dl}$ & $<\mathrm{dl}$ & $<\mathrm{dl}$ & $<\mathrm{dl}$ & $<\mathrm{dl}$ & $<\mathrm{dl}$ \\
\hline & BDE 100 & $0 \pm 0.0$ & $28.85 \pm 91.24$ & $<\mathrm{dl}$ & $7.18 \pm 14.36$ & $<\mathrm{dl}$ & $1.15 \pm 2.3$ \\
\hline & BDE 99 & $0.73 \pm 2.73$ & $<\mathrm{dl}$ & $<\mathrm{dl}$ & $<\mathrm{dl}$ & $<\mathrm{dl}$ & $<\mathrm{dl}$ \\
\hline & BDE 153 & $1.32 \pm 3.36$ & $6.44 \pm 13.78$ & $<\mathrm{dl}$ & $<\mathrm{dl}$ & $<\mathrm{dl}$ & $<\mathrm{dl}$ \\
\hline
\end{tabular}

$<\mathrm{dl}$ : below the detection limit.

\subsection{Chlorpyrifos}

Chlorpyrifos was the most frequently detected pollutant (detection frequency $=95 \%$ ) and its overall concentration ranged between < LOQ and $4551 \mathrm{ng} \mathrm{g}^{-1}$. Chlorpyrifos is the main organophosphate pesticide currently used in corn, soybean and wheat and other crops against insects and mites in Argentina, Uruguay and Brazil (Bedmar et al., 2015; CASAFE 2012; Solomon et al., 2014). It is considered ubiquitous given its main physico-chemical properties (i.e. low degradation in seawater, intermediate vapor pressure and short environmental half-life) and the possibility of undergoing long-range transport (Giesy and Solomon 2014). Levels 
of chlorpyrifos in Olrog's Gull feathers may reflect the impact of the recent use of this contaminant in extensive and intensive agricultural practices in the region. The results are in line with previous studies conducted in a range of environments in the Buenos Aires Province, northern Patagonia (Mac Loughlin et al., 2017, 2018; Villalba et al., 2020).

Subadult birds showed the highest levels of chlorpyrifos, followed by juveniles and adults. Significant differences were only found between juvenile and adult birds in both sexes (GLM $p<0.05$, Fig. 2). The breeding distribution of the Olrog's gull is chiefly restricted to southern Buenos Aires Province, with northward post-breeding migration movements along coastal areas of northern Buenos Aires Province, Uruguay and southern Brazil, and part of the population remaining in the vicinity of breeding grounds
(Copello et al., 2020). The most likely explanation related to the observed difference between juvenile and adult birds is that juvenile birds found in the Mar Chiquita coastal lagoon are likely to include individuals that recently abandoned their breeding grounds (see Fig. 1); hence supporting a potential parental trophic transfer during the previous season (Schreiber and Burger 2001). On the other hand, the transition between subadult and adult plumage in Olrog's gulls may vary between two to three years of age (Harrison 1984). Given the ability of chlorpyrifos to bioaccumulate and the high concentrations reported within Buenos Aires Province (Álvarez et al., 2013; Mac Loughlin et al., 2017; Marino and Ronco, 2005; Pérez et al., 2017; Villalba et al., 2020), the occurrence of this contaminant in feathers of older-age class gulls was expected considering the delayed molting in the species.
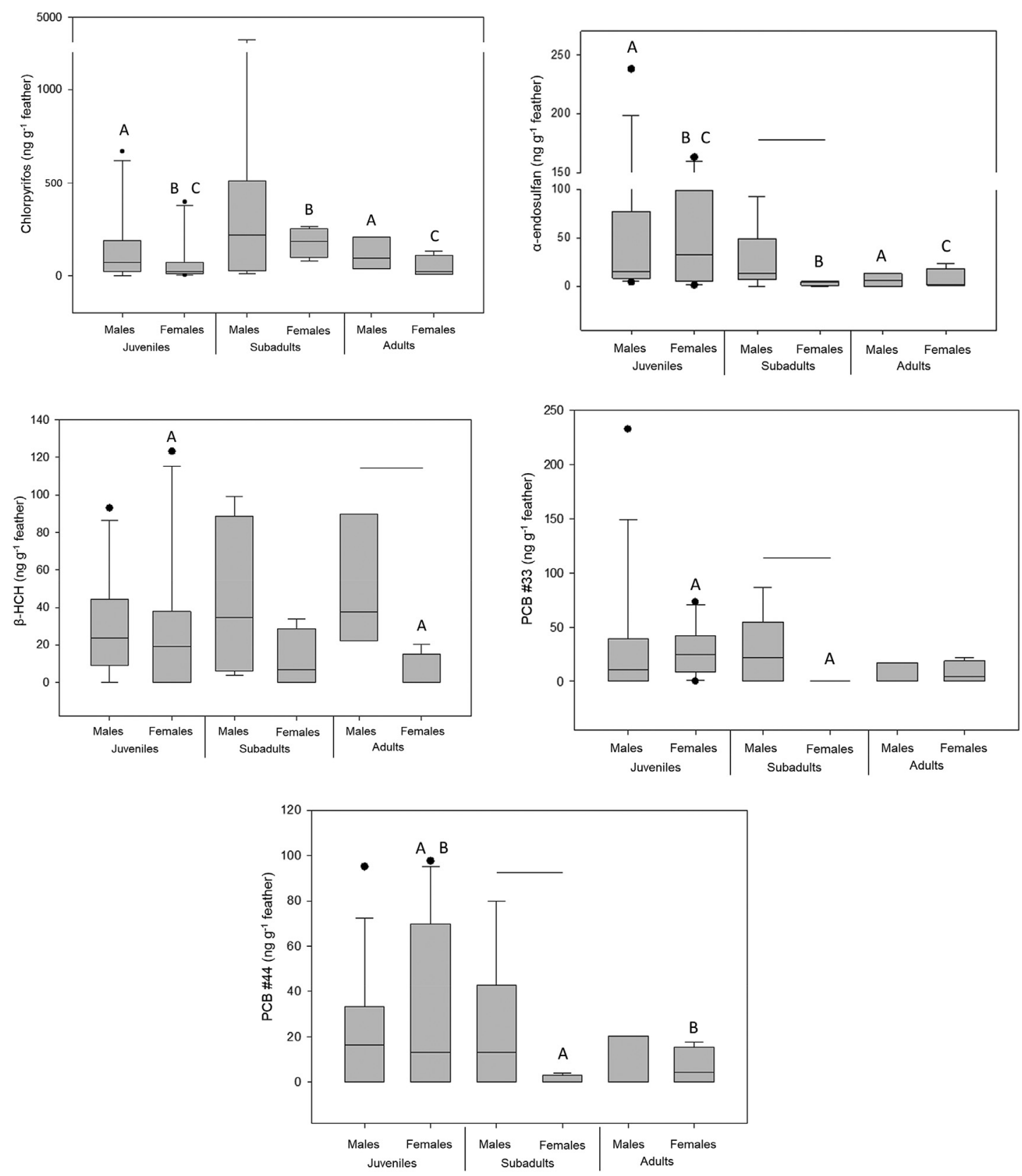

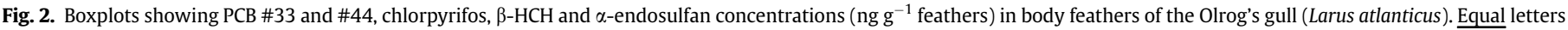

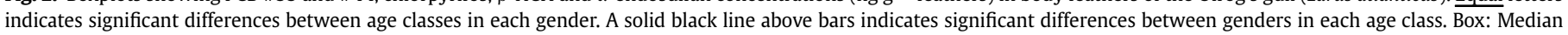
\pm SE; Whisker: Mean $\pm 2 *$ SD; Solid black circles: outliers. 
Further updated studies are needed to better elucidate the trophic niche of Olrog's gulls during the inter-breeding period, bringing also light on age class and/or sex related trophic niche segregation in the species.

\subsection{Persistent Organic Pollutants (POPs)}

Among POPs the higher average concentrations were found in OCPs followed by PCBs and PBDEs ( $132 \pm 147 ; 108 \pm 118$ and $18.5 \pm 56.4 \mathrm{ng} \mathrm{g}^{-1}$, respectively). These results are in line with those found in pelagic seabirds such as the Cape Petrel (Daption capense, $\mathrm{CAP}$ ) and the Black-browed albatross (Thalassarche melanophris, BBA) wintering in the Patagonian Shelf (Quadri Adrogué et al., 2019), although those species showed lower concentrations (CAP: OCPs $=48.1$, PCBs $=9.6$, PBDEs $=9.31 \mathrm{ng} \mathrm{g}^{-1}$; BBA: OCPs $=16.3$, $\mathrm{PCBs}=7.23$, PBDEs $=2.25 \mathrm{ng} \mathrm{g}^{-1}$ ). This could be attributed to the fact that Olrog's gulls is considered a coastal seabird (in contrast to Procellariiforms ranging in the high seas) whose distribution range along highly impacted coastal areas where pollutants are widely applied (Menone et al., 2006; Pozo et al., 2006). Studies from Norway and Ireland showed a predominance of PCBs over OCPs and PBDEs in feathers of several bird species (Acampora et al., 2017, Briels et al., 2019, Jaspers et al., 2009, Løseth et al., 2019, Svendsen et al., 2018); difference most likely linked to the more intense use of OCPs in South America than in Europe. It is known that Brazil and Argentina are the largest pesticide consumers in South America. Our results are in line with previous studies strongly indicating the higher proportion of agricultural over industrial and urban compounds in matrixes from different regions of South America (Barra et al., 2006; Miglioranza et al., 2013a, 2013b, Neves et al., 2018, Ondarza et al., 2014, Silva Barni et al., 2014).

Overall OCPs analyzed were detected in the totality of the samples (Table 1). Concentration patterns based on mean values for age class groups are depicted in Fig. 2. The predominance of endosufan and $\mathrm{HCHs}$, could be explained by their intensive use in the region and the fact that were the last OCPs banned in the region (Commendatore et al., 2018; Menone et al., 2000; Miglioranza et al., 2013a; SENASA 2013; Silva Barni et al., 2014; Villalba et al., 2020). Concentrations of endosulfans were clearly predominant over OCPs in juvenile birds while $\mathrm{HCH}$ showed the highest concentrations among those pollutants in subadults and adult birds (Fig. 3).

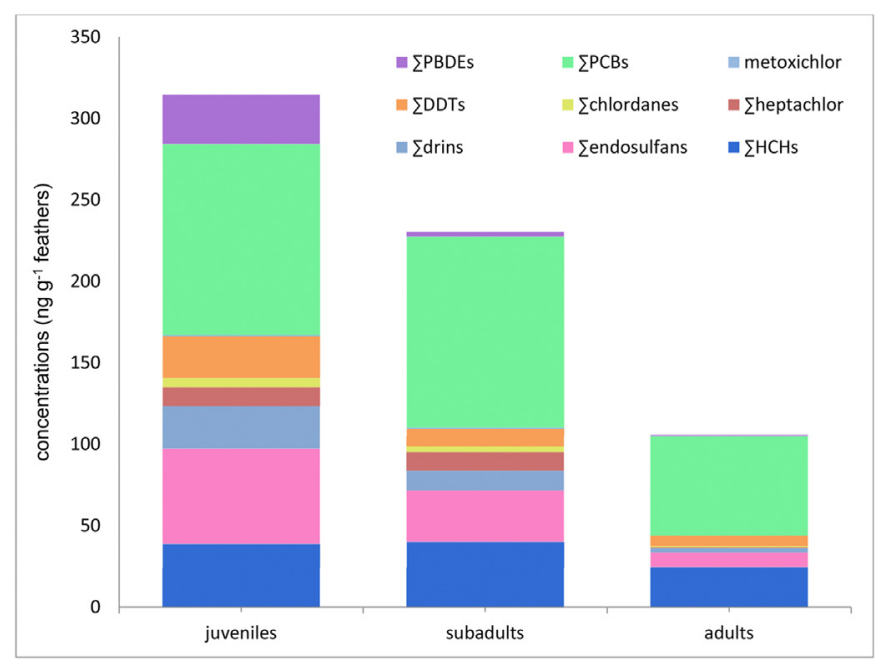

Fig. 3. Total concentrations of PBDEs, PCBs, metoxichlor, DDTs, chlordanes, heptachlors, drins, endosulfans and HCHs in juveniles, subadults and adults feathers of Olrog's gull (Larus atlanticus).
Commendatore et al. (2018) previously showed the dominance of endosulfans in Olrog's gull chicks and the presence of $\alpha$-endosulfan in chick stomach contents at a breeding colony from northern Patagonia. Given that a high proportion of the species breed in southern Buenos Aires Province, it is highly likely that at least part of the non-breeding population wintering in Mar Chiquita comes from this area. Besides, a recent study indicates that birds breeding in more southern latitudes like Bahía San Blas, shows signs of partial migration behavior during the non-breeding season (Copello et al., 2020). Thus, our results suggest that juvenile birds probably reflect the compounds they have incorporated during the breeding season. It is true that this age class may encompass older juvenile birds (second winter), hence further studies should include ringed gulls of known age so as to better understand the variation in the concentration of OCPs between birds pertaining to the same age class. Regarding endosulfan, individuals pertaining to the three ages-classes showed an $\alpha / \beta$-endosulfan ratio higher than 1 , which may indicate a recent input of technical endosulfan $(\alpha)$ $\beta=2.33$ ) in the Mar Chiquita environment. Before its prohibition, in July 2013, endosulfan was the most widely used OCP in the region (SENASA 2003) and several authors have previously reported its presence on different environmental matrixes of Argentina (Commendatore et al., 2018, Menone et al., 2000; Miglioranza et al., 2013a, 2013b, Ondarza et al., 2014, Silva Barni et al., 2014).

Birds of all age classes showed a predominance of $\beta$-HCH over $\alpha$ and $\gamma$-isomers (Table 1 ). $\beta$-HCH is the most stable isomer with the largest half-life in the environment, lowest water solubility and vapor pressure (Bachmann et al., 1988). Given that the technical $\mathrm{HCH}$ used for agricultural purposes includes only $5-14 \%$ of this isomer (Lee et al., 2001), the occurrence and high values of $\beta-\mathrm{HCH}$ in Olrog's gulls wintering in Mar Chiquita suggests that the input of $\mathrm{HCHs}$ in the environment is not recent. Sediments may act as source of 'aged' OCPs, a fraction of which may be volatilized and dispersed. This may well be the local case since previous studies have reported high values of HCHs in sediment samples gathered within the Mar Chiquita coastal lagoon (Menone et al., 2006).

Residues of DDTs were found in birds from all age classes (Table 1 ). The relative distribution of DDT and its metabolites have been regularly used to estimate the time elapsed since the application of the commercial DDT mixture. The DDE +DDD/DDT ratios were higher than 1 in almost all sampled birds, supporting the idea of the strong use of DDT insecticide during a long period of time in the region until its worldwide banning (Argentina in 1990). Since $p, p^{\prime}$-DDT is quickly metabolized to its metabolites ( $p, p^{\prime}$-DDE and $p, p$ '-DDD) (Gold and Brunk 1982), the occurrence of $p^{\prime} p$-DDT in gulls feathers likely reflect its fresh occurrence in the environment. This result may be explained by the current use of technical DDT in tropical countries, chiefly for malaria control, and the high volatility of $p^{\prime} p$-DDT transported long distances to higher latitudes, including coastal areas of Buenos Aires Province as receptor (Miglioranza et al., 2013b; Wania and Mackay 1996). Additionally, Argentinean farmers have been using Dicofol as pesticide in agricultural activities since '60s. This acaricide is synthetized from technical DDT; its impurities produced during manufacturing could reach values up to $20 \%$, thus being considered as a source of new DDT in the environment (Qiu et al., 2005).

Dieldrin was used as pesticide in soil crops before its banning in 1980; it's also the main metabolite of aldrin, more resistant to biodegradation. Endrin was employed as insecticide, rodenticide, avicide and piscicide. In the environment, it is rapidly metabolized into endrin ketone and endrin aldehyde, as a consequence of high temperatures or intense sunlight. In our study, endrin and dieldrin concentrations were found in birds of all ages; while endrin ketone was only present in juvenile birds (Table 1 ). The higher detection 
frequency of dieldrin (34\%), in comparison with endrin (9\%) and endrin ketone (5\%) may be related to the former use of aldrin and dieldrin as pesticides.

Heptachlor was one of the most widely used OCPs in Argentina for pest control on potato and cotton crops, until its prohibition in 1998. It is quickly metabolized to heptachlor epoxide, the main metabolite. In this study, heptachlor was detected in juvenile and subadult gulls, with concentrations ranging between $<$ LOD and $75.1 \mathrm{ng} \mathrm{g}^{-1}$. Heptachlor may be also deposited on feathers from the atmosphere. In this sense, Tombesi et al. (2014) have reported heptachlor, heptachlor epoxide and $\gamma$-chlordane in the atmosphere of urban centres of southern Buenos Aires Province despite its prohibition fifteen years ago. The $\alpha$ - and $\gamma$-chlordane were found in juvenile birds, subadult males and adults females showing a mean concentration of 1.94 and $2.38 \mathrm{ng} \mathrm{g}^{-1}$ respectively, probably due to the historical use of this pesticide in the region.

Birds of all age classes presented the same PCBs accumulation profile, showing the predominance of low-chlorinated PCB congeners, particularly PCB \#33, \#44 and \#31 + 28, which showed the highest concentrations (juveniles: mean $=30.5,24.7$ and $0.85 \mathrm{ng} \mathrm{g}^{-1}$; subadults: mean $=17.4,14.1$ and $10.4 \mathrm{ng} \mathrm{g}^{-1}$; adults: mean $=6.91,6.69$ and $16.5 \mathrm{ng} \mathrm{g}^{-1}$, respectively). High levels of lighter PCBs in birds, including gulls, have been previously reported by several studies, attributing the presence of low chlorinated PCBs congeners in feathers to external contamination (Acampora et al., 2017; Dauwe et al., 2005; Eulaers et al., 2011; Jaspers et al., 2007; Rajaei et al., 2011). It is well known that higher chlorinated compounds are less prominent in aquatic systems due to their lower solubility and volatility. Likewise, the high concentrations of \#153 and \#138 in juvenile birds (mean $=9.47$ and $7.23 \mathrm{ng} \mathrm{g}^{-1}$, respectively) may be explained by the compounds incorporated in eggs during the breeding season in southern Buenos Aires Province, close to urbanized and industrial areas (Yorio et al., 2013). The high concentration of hexa- and penta-CBs in that region have been previously reported in the literature, with many studies arguing the historical usage of Aroclor 1254 and 1260 mixtures (Commendatore et al., 2018; Miglioranza et al., 2013a, 2013b, Ondarza et al., 2014).

Different PBDEs patterns were observed among the three age classes (Table 1). Juveniles showed the highest concentrations (Fig. 2) where $\sum_{5}$ PBDEs were detected, while in adults and subadults, only BDE-100 was found. In juveniles BDE-100 showed the highest values (mean $=12 \mathrm{ng} \mathrm{g}^{-1}$ ) followed by BDE-47 and BDE-28 (mean $=7.38$ and $6.9 \mathrm{ng} \mathrm{g}^{-1}$, respectively). Commendatore et al. (2018) reported a similar distribution pattern in muscle tissues and stomach contents of Olrog's chicks and crab hepatopancreas from breeding grounds located in Bahía San Blas, southern Buenos Aires Province. These authors, as well as Miglioranza et al. (2013a), associated the high PBDEs levels in different matrixes with the existence of dumping sites where domestic litter like plastic and electronic waste could be illegally disposed. Those results reinforce the fact that juvenile gulls may reflect the levels of contaminants of their breeding site. In addition, bioaccumulation of BDE-47 and BDE-100 is consistent as they are the most bioaccumulative congeners among the compounds found in commercial Penta-BDE mixtures (Oros et al., 2005); such mixture containing between 75 and $98 \%$ of tetra + penta-BDE congeners. In line with it, the use of technical mixtures of penta-BDE could be an explanation for our results. The use of penta-as well as octa-mixtures have been delimited in several countries as a consequence of their ubiquitous occurrence, bioaccumulation and toxicity; both of them entered into the Stockholm Convention in 2008.

\subsection{Sex differences}

Previous seabird studies reported that during the breeding season genders show significant differences in the concentrations of organochlorines controlling for tissue sampled (Bustnes et al., 2003, 2007, 2008). However, most studies report no significant differences in the loads of these contaminants between sexes during the non-breeding season (Dauwe et al., 2005; Sagerup et al., 2009; Svendsen et al., 2018; Quadri Adrogue et al., 2019). In this study, sexual differences were observed in subadult and adult individuals (Fig. 2). Subadult males showed a tendency to higher levels of chlorpyrifos, HCHs, endosulfans, tri-, tetra- and penta-CBs than females (Table 1), but significant differences between genders were explained by $\alpha$-endosulfan, PCB-33 and PCB-44 (GLM, $p$ values $<0.05$ ). Likewise, in adult birds the same tendency was detected, in this case, males showed higher levels of chlorpyrifos, HCHs, DDTs, tri-,tetra-CBs than females (Table 1), but significant differences between sexes were only found when $\beta-\mathrm{HCH}$ was analyzed (GLM, $p$ value $<0.05$ ). Differences in pollutants levels between sexes have been attributed to egg formation, diet specialization, differential use of foraging areas, and even body-size differences (Borgå et al., 2005; Norstrom et al., 1986). In this work, the difference in pollutant loads in adult males and females could also be explained by egg formation (Johnston et al., 2001). Whereas in the case of subadult birds, which are sexually immatures, the variation in pollutant levels between sexes may be linked to the existence of a hierarchy structure or sexual dimorphism in the non-breeding population attending the Mar Chiquita coastal lagoon. However, due to the lack of associated parameters indicating genders' body-size features and role in social interactions within conspecifics, the reason for the differences in the pollutant load in this age class remains purely speculative. It could also be that individuals from this age undergo sexual habitat segregation, ranging from local differences in habitat or microhabitat to broad geographical differences. Further studies are needed to elucidate the relative contribution of sexual habitat segregation in subadult Olrog's Gulls use of space and the effect that spatial use and interaction with landscape features, including environmental and anthropogenic activities has upon pollutant concentrations in sexes of this age class.

\section{Conclusion}

To the best of our knowledge, the present study reports the first results about POPs and chlorpyrifos concentrations in the Olrog's Gull. Levels of agricultural contaminants (chlorpyrifos and OCPs) were higher than industrial and urban pollutant loads (PCBs and PBDEs) indicating the actual and historical intense pesticide application in the region. This highlights the predominance of Chlorpyrifos as the main current use pesticide in Argentina with a relative persistence in the environment, in addition to its use in other countries of South America. The highest POP concentrations found in juvenile bird feathers, over adult and subadults, may be reflecting the burden of contaminants which have been incorporated from the egg during the breeding season. Differences in pollutant levels between sexes in subadult birds could suggest the existence of a hierarchy structure and/or sexual dimorphism, where male juveniles appeared to be the dominants individuals, leading to a greater load of contaminants in males' feathers. On the other hand, in adult birds, sexual differences, showing males feathers higher levels than females ones, could be attributed to maternal transfer during the previous breeding season, sexual 
dimorphism or a combination of both. As a whole, the present study provides relevant information for the development of monitoring programs and regional strategies to improve the conservation status of the threatened Olrog's gull. Moreover, this study emphasizes the importance of using key species as biomonitors in coastal and marine environments.

\section{Funding sources}

All sampling was performed under permission and complies with current national legislation. This study was funded by the Agencia Nacional de Promoción Científica y Tecnológica, Argentina (PICT, 2015-2160 K. Miglioranza; PICT, 2015-0262 J. P. Seco Pon). The authors thank the three reviewers for their helpful and valuable comments, which greatly improved a draft of the manuscript.

\section{Declaration of competing interest}

The authors declare that they have no known competing financial interests or personal relationships that could have appeared to influence the work reported in this paper.

\section{Appendix A. Supplementary data}

Supplementary data to this article can be found online at https://doi.org/10.1016/j.envpol.2020.115918.

\section{References}

Abbasi, N.A., Arukwe, A., Jaspers, V.L.B., Eulaers, I., Mennilo, E., Ibor, O.R., Frantz, A., Covaci, A., Malik, R.N., 2017. Oxidative stress responses in relationship to persistent organic pollutant levels in feathers and blood of two predatory bird species from Pakistan. Sci. Total Environ. 580, 26-33.

Acampora, H., White, P., Lyashevska, O., O'connor, I., 2017. Presence of persistent organic pollutants in a breeding common tern (Sterna hirundo) population in Ireland. Environ. Sci. Pollut. Res. 24, 13025-13035.

Alharbi, O.M., Khattab, R.A., Ali, I., 2018. Health and environmental effects of persistent organic pollutants. J. Mol. Liq. 263, 442-453.

Álvarez, M., Du Mortier, C., Sokolic, T., Cirelli, A.F., 2013. Studies on the persistence of a commercial formulation of chlorpyrifos on an agricultural soil from Provincia de Buenos Aires, República Argentina. Water Air Soil Pollut. 224, 1571.

Anderson, O.R.J., Phillips, R.A., Shore, R.F., McGill, R.A.R., McDonald, R.A., Bearhop, S., 2010. Element patterns in albatrosses and petrels: influence of trophic position, foraging range, and prey type. Environ. Pollut. 158, 98-107.

Bachmann, A., Walet, P., Wijnen, P., De Bruin, W., Huntjens, J.L., Roelofsen, W., Zehnder, A.J., 1988. Biodegradation of alpha-and beta-hexachlorocyclohexane in a soil slurry under different redox conditions. Appl. Environ. Microbiol. 54, $143-149$.

Barra, R., Colombo, J.C., Eguren, G., Gamboa, N., Jardim, W.F., Mendoza, G., 2006. Persistent organic pollutants (POPs) in eastern and western south American countries. In: Ware, G.W. (Ed.), Rev Environ Contam T. Springer, USA, pp. 1-33.

Bedmar, F., Gianelli, V.R., Angelini, H.P., Viglianchino, L.E., 2015. Riesgo de contaminación del agua subterránea con plaguicidas en la cuenca del arroyo El Cardalito, Argentina. Gerencia de Comunicación e Imagen Institucional, DNA SICC, INTA.

Behrooz, R.D., Esmaili-Sari, A., Ghasempouri, S.M., Bahramifar, N., Covaci, A., 2009. Organochlorine pesticide and polychlorinated biphenyl residues in feathers of birds from different trophic levels of south-west Iran. Environ. Int. 35, 285-290.

Berón, M.P., 2003. Dieta de juveniles de Gaviota Cangrejera (Larus atlanticus) en estuarios de la Provincia de Buenos Aires. Hornero 18, 113-117.

Berón, M.P., Favero, M., 2010. Monitoreo de la dieta de la Gaviota de Olrog (Larus atlanticus) en la Laguna Mar Chiquita (Buenos Aires, Argentina) durante el período no reproductivo. Ornitol. Neotrop. 21, 215-224.

Berón, M.P., Favero, M., Gómez-Laich, A., 2007. Use of natural and anthropogenic resources by the Olrog's Gull Larus atlanticus: implications for the conservation of the species in nonbreeding habitats. Bird. Conserv. Int. 17, 351-357.

Berón, M.P., Caballero-Sadi, D., García, G.O., Paterlini, C.A., Favero, M., Seco Pon, J.P., 2012. Espectro trófico de la Gaviota de Olrog (Larus atlanticus) en dos sitios de invernada de Argentina y Uruguay. Ornithol Neotrop 23, 83-93.

BirdLife International, 2018. State of the world's birds. Available from. http:// datazone.birdlife.org/sowb. (Accessed 22 April 2019).

Bloom, P.H., 1987. Capturing and handling raptors. In: raptor management techniques manual. In: Giron Pendelton, B.A., Millsap, B.A., Cline, K.W., Bird, D.M. (Eds.), Science and Technology Series No. 10. National Wildlife Federal Service, USA, pp. 99-123.

Borgå, K., Wolkers, H., Skaare, J.U., Hop, H., Muir, D.C., Gabrielsen, G.W., 2005.
Bioaccumulation of PCBs in Arctic seabirds: influence of dietary exposure and congener biotransformation. Environ. Pollut. 134, 397-409.

Burger, J., 1993. Metals in avian feathers: bioindicators of environmental pollution. Rev. Environ. Toxicol. 5, 203-311.

Burger, J., Gochfeld, M., 2002. Effects of chemicals and pollution on seabirds. In: Schreiber, E.A., Burger, J. (Eds.), Biology of Marine Birds. CRC press, pp. 485-525.

Burger, J., Gochfeld, M., 2004. Marine birds and sentinels of environmental pollution. EcoHealth 1, 263-274.

Burger, J., Nisbet, I.C.T., Gochfeld, M., 1994. Heavy metal and selenium levels in feathers of known-aged Common terns Sterna hirundo. Arch Environ Con Tox $26,351-355$.

Bustnes, J.O., Bakken, V., Skaare, J.U., Erikstad, K.E., 2003. Age and accumulation of persistent organochlorines: a study of arctic breeding glaucous gulls. Environ. Toxicol. Chem. 22, 2173-2179.

Bustnes, J.O., Tveraa, T., Henden, J.A., Varpe, Ø., Skaare, J.U., 2007. Reproductive performance and organochlorine pollutants in an Antarctic marine top predator: the south polar skua. Environ. Int. 33, 911-918.

Bustnes, J.O., Tveraa, T., Fauchald, P., Helberg, M., Skaare, J.U., 2008. The potential impact of environmental variation on the concentrations and ecological effects of pollutants in a marine avian top predator. Environ. Int. 34, 193-201.

Cámara Argentina de Sanidad Agropecuaria y Fertilizantes (CASAFE), 2012. Mercado Argentino de Productos Fitosanitarios. http://www.casafe.org/publicaciones/ estadisticas.

Commendatore, M., Yorio, P., Scenna, L., Ondarza, P.M., Suárez, N., Marinao, C., Miglioranza, K.S., 2018. Persistent organic pollutants in sediments, intertidal crabs, and the threatened Olrog's gull in a northern Patagonia salt marsh, Argentina. Mar. Pollut. Bull. 136, 533-546.

Copello, S., Favero, M., 2001. Foraging ecology of Olrog"s gull Larus atlanticus in mar Chiquita lagoon (Buenos Aires, Argentina): are there age-related differences? Bird. Conserv. Int. 11, 175-188.

Copello, S., Suárez, N., Yorio, P., Ravasi, M.T., García Borboroglu, J.P., Graña Grilli, M., Favero, M., Seco Pon, J.P., 2020. Distribution of Olrog's Gull (Larus atlanticus) during the non-breeding period: signals of partial migration. Bird. Conserv. Int. $1-10$.

Crawley, M.J., 2007. The R Book. John Wiley and Sons, USA.

Convention on the Conservation of Migratory Species of Wild Animals (CMS), 2018. Appendices I and II of the CMS.

Dauwe, T., Jaspers, V., Covaci, A., Schepens, P., Eens, M., 2005. Feathers as a nondestructive biomonitor for persistent organic pollutants. Environ. Toxicol. Chem. 24, 442-449.

Devillers, P., 1977. Observations at a breeding colony of Larus (Belcheri) atlanticus. Gerfaut 67, 22-43.

Durante, C.A., Santos-Neto, E.B., Azevedo, A., Crespo, E.A., Lailson-Brito, J., 2016 POPs in the South Latin America: bioaccumulation of DDT, PCB, HCB, $\mathrm{HCH}$ and Mirex in blubber of common dolphin (Delphinus delphis) and Fraser's dolphin (Lagenodelphis hosei) from Argentina. Sci. Total Environ. 572, 352-360.

Eng, M.L., Stutchbury, B.J., Morrissey, C.A., 2017. Imidacloprid and Chlorpyrifos insecticides impair migratory ability in a seed-eating songbird. Sci Rep-UK 7 , 15176.

Eulaers, I., Covaci, A., Hofman, J., Nygård, T., Halley, D.J., Pinxten, R., Eens, M., Jaspers, V.L.B., 2011. A comparison of non-destructive sampling strategies to assess the exposure of white-tailed eagle nestlings (Haliaeetus albicilla) to persistent organic pollutants. Sci. Total Environ. 410, 258-265.

Fromant, A., Carravieri, A., Bustamante, P., Labadie, P., Budzinski, H., Peluhet, L., Churlaud, C., Chastel, O., Cherel, Y., 2016. Wide range of metallic and organic contaminants in various tissues of the Antarctic prion, a planktonophagous seabird from the Southern Ocean. Sci. Total Environ. 544, 754-764.

Fry, D.M., 1995. Reproductive effects in birds exposed to pesticides and industrial chemicals. Environ. Health Perspect. 103, 165-171.

Furness, R.W., Greenwood, J.J.D., Jarvis, P.J., 1993. Can birds Be used to monitor the environment? In: Furness, R. W. y, Greenwood, J.J.D. (Eds.), Birds as Monitors of Environmental Change. Chapman \& Hal., UK, pp. 1-41.

Garcia Borboroglu, P., Yorio, P., 2007. Breeding habitat requirements and selection by Olrog's Gull (Larus atlanticus), a threatened species. Auk 124, 1201-1212.

García-Fernández, A.J., Espín, S., Martínez-López, E., 2013. Feathers as a biomonitoring tool of polyhalogenated compounds: a review. Environ. Sci. Technol. 47, 3028-3043.

Gervais, J.A., Rosenberg, D.K., Fry, D.M., Trulio, L., Sturm, K.K., 2000. Burrowing owls and agricultural pesticides: evaluation of residues and risks for three populations in California, USA. Environ. Toxicol. Chem. 19, 337-343.

Giesy, J.P., Solomon, K.A., 2014. Ecological Risk Assessment for Chlorpyrifos in Terrestrial and Aquatic Systems in North America. Springer.

Gill, F.B., 2007. Ornithology. Macmillan.

Gold, B., Brunk, G., 1982. Metabolism of 1, 1, 1-trichloro-2, 2-bis (p-chlorophenyl) ethane and 1,1-dichloro-2, 2-bis (p-chlorophenyl) ethane in the mouse. Chem. Biol. Interact. 41, 327-339.

Gómez-Ramírez, P., Martínez-López, E., García-Fernández, A.J., Zweers, A.J., van den Brink, N.W., 2012. Organohalogen exposure in a Eurasian Eagle owl (Bubo bubo) population from Southeastern Spain: temporal-spatial trends and risk assessment. Chemosphere 88, 903-911.

Hardy, J., Crick, H., Wernham, C., Riley, H., Etheridge, B., Thompson, D., 2006. Feathers. Raptors: a Field Guide for Surveys and Monitoring. The Stationery Office, Edinburgh, pp. 243-280.

Harrison, P., 1984. Seabirds. An Identification Guide. Houghton Mifflin Company, USA. 
Herrera, G., Punta, G., Yorio, P., 2005. Diet specialization of the threatened Olrog's gull Larus atlanticus during the breeding season at Golfo San Jorge, Argentina. Bird. Conserv. Int. 15, 89-97.

Iribarne, O., 2001. Reserva de Biosfera Mar Chiquita: Características físicas, biológicas y ecológicas. Editorial Martín, Argentina.

Isacch, J.P., 2008. Implementing the biosphere reserve concept: the case of Parque Altántico Mar Chiquito biosphere reserve from Argentina. Biodivers. Conserv. 17, 1799-1804.

Isacch, J., Bó, M., Vega, L., Favero, M., Baladrón, A., Pretelli, M., Stellatelli, O., Cardoni, D., Copello, S., Block, C., Cavalli, M., Comparatore, V., MarianoJelicich, R., Biondi, L.M., García, G., Seco Pon, J.P., 2016. Evaluación de la diversidad de Tetrápodos en un mosaico de ambientes del sudeste de la ecoregión Pampeana como herramienta para planificar en conservación. Revista del Museo Argentino de Ciencias Naturales "Bernardino Rivadavia” 18, 211-233.

Isla, F.I., Lasta, C.A., 2006. Manual de manejo costero para la Provincia de Buenos Aires, first ed. EUDEM, Mar del Plata, Argentina.

Isla, F.I., Lasta, C.A., 2010. Manual de manejo de barreras medanosas de la Provincia de Buenos Aires, first ed. EUDEM, Mar del Plata, Argentina.

Jaspers, V.L.B., Covaci, A., Voorspoels, S., Dauwe, T., Eens, M., Schepens, P., 2006. Brominated flame retardants and organochlorine pollutants in aquatic and terrestrial predatory birds of Belgium: levels, patterns, tissue distribution and condition factors. Environ. Pollut. 139, 340-352.

Jaspers, V.L.B., Voorspoels, S., Covaci, A., Lepoint, G., Eens, M., 2007. Evaluation of the usefulness of bird feathers as a non-destructive biomonitoring tool for organic pollutants: a comparative and meta-analytical approach. Environ. Int. 33, 328-337.

Jaspers, V.L.B., Covaci, A., Deleu, P., Neels, H., Eens, M., 2009. Concentrations in bird feathers reflect regional contamination with organic pollutants. Sci. Total Environ. 407, 1447-1451.

Jaspers, V.L.B., Rodriguez, F.S., Boertmann, D., Sonne, C., Dietz, R., Rasmussen, L.M., Eens, M., Covaci, A., 2011. Body feathers as a potential new biomonitoring tool in raptors: a study on organohalogenated contaminants in different feather types and preen oil of West Greenland white-tailed eagles (Haliaeetus albicilla). Environ. Int. 37, 1349-1356.

Jaspers, V.L., Covaci, A., Herzke, D., Eulaers, I., Eens, M., 2019. Bird feathers as a biomonitor for environmental pollutants: prospects and pitfalls. TrAC Trends Anal. Chem. (Reference Ed.) 118, 223-226.

Johnston, T.A., Bodaly, R.A., Latif, M.A., Fudge, R.J.P., Strange, N.E., 2001. Intra-and interpopulation variability in maternal transfer of mercury to eggs of walleye (Stizostedion vitreum). Aquat. Toxicol. 52, 73-85.

Keith, L.H., Crumett, W., Wentler, G., 1983. Principles of environmental analysis. Anal. Chem. 55, 2210-2218.

Laterra, P., Nahuelhual, L., Gluch, M., Sirimarco, X., Bravo, G., Monjeau, A., 2019. How are jobs and ecosystem services linked at the local scale? Ecosyst serv 35, $207-218$.

Lee, K.T., Tanabe, S., Koh, C.H., 2001. Distribution of organochlorine pesticides in sediments from Kyeonggi Bay and nearby areas, Korea. Environ. Pollut. 114, 207-213.

Lohmann, R., Breivik, K., Dachs, J., Muir, D., 2007. Global fate of POPs: current and futureresearch directions. Environ. Pollut. 150, 150-165.

Løseth, M.E., Briels, N., Flo, J., Malarvannan, G., Poma, G., Covaci, A., Herzke, D., Nygård, T., Bustnes, J.O., Jenssen, B.M., Jaspers, V.L., 2019. White-tailed eagle (Haliaeetus albicilla) feathers from Norway are suitable for monitoring of legacy, but not emerging contaminants. Sci. Total Environ. 647, 525-533.

Lucifora, L.O., 2001. Tiburones y pesca de tiburones en Mar Chiquita. Reserva de Biosfera Mar Chiquita: Características físicas, biológicas y ecológicas, pp. 205-206.

Mac Loughlin, T.M., Peluso, L., Marino, D.J., 2017. Pesticide impact study in the periurban horticultural area of Gran La Plata, Argentina. Sci. Total Environ. 598, $572-580$.

Mac Loughlin, T.M., Peluso, M.L., Etchegoyen, M.A., Alonso, L.L., de Castro, M.C., Percudani, M.C., Marino, D.J., 2018. Pesticide residues in fruits and vegetables of the argentine domestic market: occurrence and quality. Food Contr. 93, 129-138.

Mackay, D., Giesy, J.P., Solomon, K.R., 2014. Fate in the environment and long-range atmospheric transport of the organophosphorus insecticide, Chlorpyrifos and its oxon. In: Giesy, J., Solomon, K. (Eds.), Ecological Risk Assessment for Chlorpyrifos in Terrestrial and Aquatic Systems in the United States - Rev Environ Contam T. Springer, USA, pp. 35-76.

Marino, D., Ronco, A., 2005. Cypermethrin and chlorpyrifos concentration levels in surface water bodies of the Pampa Ondulada, Argentina. Bull. Environ. Contam. Toxicol. 75, 820-826.

Martínez, M.M., Isaach, J.P., Rojas, M., 2000. Olrog's Gull Larus atlanticus: specialist of generalist? Bird. Conserv. Int. 10, 89-92.

Menone, M.L., Miglioranza, K.S., Botto, F., Iribarne, O., de Moreno, J.E.A., Moreno, V.J., 2006. Field accumulative behavior of organochlorine pesticides. The role of crabs and sediment characteristics in coastal environments. Mar. Pollut. Bull. 52, 1717-1724.

Menone, M.L., De Moreno, J.A., Moreno, V.J., Lanfranchi, A.L., Metcalfe, T.L., Metcalfe, C.D., 2000. PCBs and organochlorines in tissues of silverside (Odontesthes bonariensis) from a coastal lagoon in Argentina. Arch. Environ. Contam. Toxicol. 38, 202-208.

Miglioranza, K.S.B., Aizpún de Moreno, J.E., Moreno, V.J., Osterrieth, M.L., Escalante, A.H., 1999. Fate of organochlorine pesticides in soils and terrestrial biota of "Los Padres" pond watershed, Argentina. Environ. Pollut. 105, 91-99.
Miglioranza, K.S.B., Aizpún de Moreno, J.E., Moreno, V.J., 2003. Dynamics of organochlorine pesticides in soils from a southeastern region of Argentina. Environ. Toxicol. Chem. 22, 712-717.

Miglioranza, K.S., Gonzalez, M., Ondarza, P.M., Shimabukuro, V.M., Isla, F.I., Fillmann, G., Aizpún, J.E., Moreno, V.J., 2013a. Assessment of Argentinean Patagonia pollution: PBDEs, OCPs and PCBs in different matrices from the Río Negro basin. Sci. Total Environ. 452, 275-285.

Miglioranza, K.S.B., Gonzalez, M., Ondarza, P.M., Mitton, F.M., Grondona, S., Shimabukuro, V.M., Barra, R., Fillmann, G., 2013b. Assessment of persistent organic pollutant in the atmosphere of Latin America. Occurrence, fate and impact of atmospheric pollutants on environmental and human health, 1149. ACS Symposium Series (Chapter 9)pp. 183-199.

Ministerio de Ambiente y Desarrollo Sustentable y Aves ArgentinaS (MAyDS, and AA), 2017. Categorización de las Aves de la Argentina (2015). In: Informe del Ministerio de Ambiente y Desarrollo Sustentable de la Nación y de Aves Argentinas, edición electrónica. C. A., Buenos Aires, Argentina).

Mitra, A., Chatterjee, C., Mandal, F.B., 2011. Synthetic chemical pesticides and their effects on birds. Res J Environ Toxicol 5, 81-96.

Monclús, L., Lopez-Bejar, M., De la Puente, J., Covaci, A., Jaspers, V.L.B., 2018. First evaluation of the use of down feathers for monitoring persistent organic pollutants and organophosphate ester flame retardants: a pilot study using nestlings of the endangered cinereous vulture (Aegypius monachus). Environ. Pollut. 238, 413-420.

Neves, P.A., Colabuono, F.I., Ferreira, P.A., Kawakami, S.K., Taniguchi, S., Figueira, R.C., Mahiques, M.M., Montone, R.C., Bícego, M.C., 2018. Depositional history of polychlorinated biphenyls (PCBs), organochlorine pesticides (OCPs) and polycyclic aromatic hydrocarbons (PAHs) in an Amazon estuary during the last century. Sci. Total Environ. 615, 1262-1270.

Norstrom, R.J., Clark, T.P., Jeffrey, D.A., Won, H.T., Gilman, A.P., 1986. Dynamics of organochlorine compounds in herring gulls (Larus argentatus): I. Distribution and clearance of [14C] DDE in free-living herring gulls (Larus argentatus). Environ. Toxicol. Chem. 5, 41-48.

Olrog, C.C., 1967. Breeding of the band-tailed gull ( . belcheri) on the atlantic coast of Argentina. Condor 69, 42-48.

Ondarza, P.M., Gonzalez, M., Fillmann, G., Miglioranza, K.S.B., 2014. PBDEs, PCBs and organochlorine pesticides distribution in edible fish from Negro River basin, Argentinean Patagonia. Chemosphere 94, 135-142.

Oros, D., Hoover, D., Rodigari, F., Crane, D., Sericano, J., 2005. Levels and distribution of polybrominated diphenyl ethers in water, surface sediments, and bivalves from the San Francisco Estuary. Environ. Sci. Technol. 39, 33-41.

Pérez, D.J., Okada, E., De Gerónimo, E., Menone, M.L., Aparicio, V.C., Costa, J.L., 2017. Spatial and temporal trends and flow dynamics of glyphosate and other pesticides within an agricultural watershed in Argentina. Environ. Toxicol. Chem. $36,3206-3216$

Pozo, K., Harner, T., Wania, F., Muir, D.C.G., Jones, K.C., Barrie, L.A., 2006. Toward a global network for persistent organic pollutants in air: results from the GAPS study. Sci Technol Branch 1.

Qiu, X., Zhu, T., Yao, B., Hu, J., Hu, S., 2005. Contribution of Dicofol to the current DDT pollution in China. Environ. Sci. Technol. 39, 4385-4390.

Qiu, Y.W., Qiu, H.L., Zhang, G., Li, J., 2019. Bioaccumulation and cycling of organochlorine pesticides (OCPs) and polychlorinated biphenyls (PCBS) in three mangrove reserves of south China. Chemosphere 217, 195-203.

Quadri Adrogué, A., Miglioranza, K.S., Copello, S., Favero, M., Seco Pon, J.P., 2019. Pelagic seabirds as biomonitors of persistent organic pollutants in the Southwestern Atlantic. Mar. Pollut. Bull. 149, 110516.

Quintana, F., López, G., Somoza, G., 2008. A cheap and quick method for DNA-based sexing of birds. Waterbirds 31, 485-488.

R Development Core Team, 2019. R: a language and environment for statistical computing. Available from:. R Foundation for Statistical Computing, Vienna, Austria http://www.R-project.org.

Rajaei, F., Sari, A.E., Bahramifar, N., Savabieasfahani, M., Ghasempouri, M., 2011. Persistent organic pollutants in muscle and feather of ten avian species from Māzandarān Province of Iran, on the coast of the Caspian Sea. Bull. Environ. Contam. Toxicol. 87, 678-683.

Sagerup, K., Helgason, L.B., Polder, A., Strøm, H., Josefsen, T.D., Skåre, J.U., Gabrielsen, G.W., 2009. Persistent organic pollutants and mercury in dead and dying glaucous gulls (Larus hyperboreus) at Bjørnøya (Svalbard). Sci. Total Environ. 407, 6009-6016.

Schreiber, E.A., Burger, J. (Eds.), 2001. Biology of Marine Birds. CRC press.

Seco Pon, J.P., García, G., Copello, S., Moretinni, A., Lértora, H.P., Pedrana, J., Mauco, L., Favero, M., 2012. Seabird and marine mammal attendance in the Chub mackerel Scomber japonicus semi-industrial Argentinian purse seine fishery. Ocean coast manage 64, 56-66.

Servicio Nacional de Sanidad y Calidad Agroalimentaria (SENASA), 2013. Ministerio de Agricultura, Ganadería y Pesca de la Nación Argentina. www.senasa.gov.ar.

Silva Barni, M.F., Gonzalez, M., Miglioranza, K.S., 2014. Assessment of persistent organic pollutants accumulation and lipid peroxidation in two reproductive stages of wild silverside (Odontesthes bonariensis). Ecotoxicol. Environ. Saf. 99, 45-53.

Solomon, K.R., Williams, W.M., Mackay, D., Purdy, J., Giddings, J.M., Giesy, J.P., 2014 Properties and uses of chlorpyrifos in the United States. Ecological Risk Assessment for Chlorpyrifos in Terrestrial and Aquatic Systems in the United States. Springer, Cham, pp. 13-34.

Soriano, A., León, R.J., Sala, O.E., Lavado, S., Deregibus, V.A., Cauhepé, M.A., Scaglia, O.A., Velásquez, A.C., Lemcoff, J.H., 1991. Río de la Plata grasslands. In: 
Coupland, R.T. (Ed.), Ecosystems of the World 8A, Natural Grasslands, Introduction and Western Hemisphere. Elsevier Press, New York, pp. 367-407.

Spivak, E.D., Sánchez, N., 1992. Prey selection by larus-belcheri-atlanticus in mar Chiquita lagoon, buenos-aires, Argentina-a possible explanation for its discontinuous distribution. Rev. Chil. Hist. Nat. 65, 209-220.

Sun, J., Covaci, A., Bustnes, J.O., Jaspers, V.L.B., Helander, B., Bårdsen, B.J., Boertmann, D., Dietz, R., Labansen, A.L., Lepoint, G., Schulz, R., Malarvannan, G., Sonne, C., Thorup, K., Tøttrup, A.P., Zubrod, J.P., Eens, M., Eulaers, I., 2020. Temporal trends of legacy organochlorines in different white-tailed eagle (Haliaeetus albicilla) subpopulations: a retrospective investigation using archived feathers. Environ. Int. 138, 105618.

Svendsen, N.B., Herzke, D., Harju, M., Bech, C., Gabrielsen, G.W., Jaspers, V.L.B., 2018. Persistent organic pollutants and organophosphate esters in feathers and blood plasma of adult kittiwakes (Rissa tridactyla) from Svalbard-associations with body condition and thyroid hormones. Environ. Res. 164, 158-164.

Tombesi, N. Pozo, K., Harner, T., 2014. Persistent organic pollutants (POPs) in the atmosphere of agricultural and urban areas in the province of Buenos Aires in Argentina using PUF disk passive air samplers. Atmos Pollut Res 5, 170-178.

United Nations Environmental Programme (UNEP), 2011. United Nations
Environmental Programme (UNEP). 2011. Draft Revised Guidance on the Global Monitoring Plan for Persistent Organic Pollutants. Document UNEP/POPS/ COP.5/INF/27, 09.15.2020.

Villalba, A., Maggi, M., Ondarza, P.M., Szawarski, N., Miglioranza, K.S.B., 2020. Influence of land use on chlorpyrifos and persistent organic pollutant levels in honey bees, bee bread and honey: beehive exposure assessment. Sci. Total Environ. 713, 136554.

Wania, F., Mackay, D., 1996. Tracking the distribution of persistent organic pollutants. Environ. Sci. Technol. 30, 390-396.

Yorio, P., Frere, E., Gandini, P., Harris, G., 1998. Atlas de la distribución reproductiva de aves marinas en el litoral patagónico argentino. Fundación Patagonia Natural, Argentina.

Yorio, P., Bertellotti, M., Borboroglu, P.G., 2005. Estado poblacional y de conservación de gaviotas que se reproducen en el litoral marítimo Argentino. Hornero 20, 53-74.

Yorio, P., Marinao, C., Retana, M.V., Suárez, N., 2013. Differential use of food resources between the kelp gull Larus dominicanus and the threatened Olrog's gull L. atlanticus. ARDEOLA 60, 29-44. 